\title{
FAKTOR YANG BERHUBUNGAN DENGAN PERILAKU PEMBERIAN ASI EKSKLUSIF DI KELURAHAN PEGIRIAN KECAMATAN SEMAMPIR KOTA SURABAYA
}

\author{
Ria Indah Erfiyani, Nuria \\ Biostatistika dan Kependudukan, Universitas Airlangga \\ E-mail: ria.indah.erfiyani-2016@ fkm.unair.ac.id
}

\begin{abstract}
Maternal mortality rate $(M M R)$ and infant mortality rate (IMR) are one of indicators to determine public health status. Exclusive breast milk is an effort that can be done to reduce the IMR. Breast milk is the first food for babies who can meet nutritional needs in the first six months of life. Most Indonesian people still provide additional food to babies aged 0-6 months. In fact, the success of exclusive breastfeeding plays an important role in the continuity of breastfeeding in infants up to the age of 2 years. Therefore, researchers are interested in conducting research on factors related to exclusive breastfeeding behavior. This study was an observational study conducted in the RT $06 R W$ 02 Pegirian Village, Semampir Subdistrict, Surabaya City in January 2018. The data used was secondary data from the Field Work Practices (PKL) activities of FKM Students at Airlangga University. The study subjects were women of childbearing age (WUS) aged 15-49 years who were married and had had children. The data used are working status data, level of education, as well as knowledge, attitudes, and behavior of mothers regarding exclusive breastfeeding. The results showed there was no significant relationship between work status ( $p$ value 0.958) and education level ( $p$ value 0.753 ) with exclusive breastfeeding behavior. There is a relationship between knowledge ( $p$ value 0.008 ) and attitude ( $p$ value 0.047) with exclusive breastfeeding behavior. The conclusion obtained is that there is a significant relationship between knowledge and attitudes with exclusive breastfeeding behavior. This happens because knowledge will shape attitudes, then attitudes will shape behavior to give exclusive breastfeeding.
\end{abstract}

Keywords: Exclusive Breastfeeding, Knowledge, Attitude

\begin{abstract}
ABSTRAK
AKI dan AKB merupakan salah satu indikator untuk mengetahui status kesehatan masyarakat. Air Susu Ibu (ASI) eksklusif merupakan upaya yang dapat dilakukan untuk menurunkan AKB. ASI merupakan makanan pertama untuk bayi yang dapat memenuhi kebutuhan nutrisi dalam enam bulan pertama kehidupan. Kebanyakan masyarakat Indonesia masih memberikan makanan tambahan kepada bayi usia 0-6 bulan. Padahal, keberhasilan pemberian ASI eksklusif berperan penting terhadap kelangsungan pemberian ASI pada bayi sampai usia 2 tahun. Oleh karena itu, peneliti tertarik untuk melakukan penelitian mengenai faktor yang berhubungan dengan perilaku pemberian ASI eksklusif. Penelitian ini merupakan penelitian observasional yang dilakukan di wilayah RT 06 RW 02 Kelurahan Pegirian Kecamatan Semampir Kota Surabaya pada bulan Januari 2018. Data yang digunakan merupakan data sekunder dari kegiatan Praktik Kerja Lapangan (PKL) Mahasiswa FKM
\end{abstract}


Universitas Airlangga. Subjek penelitian merupakan wanita usia subur (WUS) berusia 15-49 tahun yang telah menikah dan pernah memiliki anak. Data yang digunakan merupakan data status bekerja, tingkat pendidikan, serta pengetahuan, sikap, dan perilaku ibu terkait ASI eksklusif. Hasil penelitian menunjukkan tidak ada hubungan yang signifikan antara status bekerja ( $p$ value 0,958$)$ dan tingkat pendidikan ( $p$ value 0,753) dengan perilaku pemberian ASI eksklusif. Ada hubungan antara pengetahuan ( $p$ value 0,008$)$ dan sikap ( $p$ value 0,047$)$ dengan perilaku pemberian ASI eksklusif. Kesimpulan yang didapatkan adalah terdapat hubungan yang bermakna antara pengetahuan dan sikap dengan perilaku pemberian ASI eksklusif. Hal tersebut terjadi karena pengetahuan akan membentuk sikap, kemudian sikap akan membentuk perilaku untuk memberikan ASI eksklusif.

Kata kunci: ASI Eksklusif, Pengetahuan, Sikap

\section{PENDAHULUAN}

Status kesehatan masyarakat di suatu negara dapat dilihat dari seberapa tinggi dan rendahnya Angka Kematian Ibu (AKI) dan Angka Kematian Bayi (AKB) di negara tersebut. Angka kematian bayi seringkali disebabkan oleh penyakit infeksi saluran pernafasan akut (ISPA) dan diare. World Health Organization (WHO) memperkirakan bahwa 53\% kematian bayi akibat kasus pneumonia akut dan 55\% kematian bayi akibat kasus diare disebabkan oleh pemberian makanan yang buruk pada enam bulan pertama kehidupan. ${ }^{1}$

Air Susu Ibu (ASI) eksklusif merupakan upaya yang dapat dilakukan untuk menurunkan angka kematian bayi (AKB). ASI merupakan makanan pertama dan alami bagi bayi yang mengandung berbagai macam vitamin, mineral, dan nutrisi lainnya yang sesuai bagi kebutuhan bayi dalam enam bulan pertama kehidupan. Selain kandungan nutrisi, ASI juga mengandung IgA, IgM, IgG, IgE, laktoferin, lisosom, immunoglobulin, dan zat lainnya yang merupakan zat kekebalan bagi tubuh bayi sehingga tubuh bayi dapat terhindar dari berbagai macam penyakit infeksi. ${ }^{2}$ Oleh karena itu, dalam dua tahun pertama kehidupan, setengah atau lebih kebutuhan gizi dapat terpenuhi oleh pemberian ASI pada bayi. ${ }^{3}$

Setiap tahunnya, lebih dari 136 juta bayi dilahirkan. Akan tetapi hingga 6 bulan pertama kehidupan, terdapat 92 juta bayi yang tidak memperoleh ASI eksklusif. ${ }^{1}$ Cakupan ASI eksklusif pada tahun 2009 yaitu sebesar 34,3\% dan pada tahun 2010 menurun menjadi 33,6\%. ${ }^{4}$ Menurut data Riset Kesehatan Dasar (Riskesdas) tahun 2013 cakupan ASI eksklusif pada bayi usia 0-1 bulan sebesar 48,7\%. Angka ini menurun menjadi $42,2 \%$ pada bayi usia $2-3$ bulan. Kemudian menurun lagi menjadi sebesar 36,6\% pada bayi berusia 4-5 bulan. Akhirnya, pada bayi usia 6 bulan semakin menurun menjadi sebesar 30,2\%..$^{5}$ Angka tersebut masih jauh dari target cakupan ASI nasional yaitu sebesar $80 \%$.

Cakupan pemberian ASI eksklusif di Jawa Timur pada tahun 2017 adalah sebesar 75,7\%. Angka tersebut telah meningkat dibandingkan 
dengan tahun 2016 yang baru mencapai 74,5\%. Peningkatan tersebut menunjukkan bahwa para ibu telah memahami tentang pentingnya ASI eksklusif bagi bayi. ${ }^{6}$

Dibandingkan dengan capaian Provinsi Jawa Timur, cakupan ASI eksklusif di Kota Surabaya masih lebih rendah, yaitu sebesar 65,1\%. Padahal, Kota Surabaya merupakan kota dengan jumlah kelahiran hidup tertinggi di Jawa Timur, yaitu 42.822. Sedangkan, angka kematian bayi menempati posisi kedua dengan jumlah kematian sebanyak 219 jiwa. $^{6}$

Salah satu kecamatan yang berada di wilayah geografis Kota Surabaya bagian utara yaitu Kecamatan Semampir. Terdapat 5 kelurahan pada Kecamatan Semampir, yaitu Kelurahan Sidotopo, Ampel, Wonokusumo, Ujung, dan Pegirian. Tahun 2016, jumlah penduduk total di Kecamatan Semampir yaitu mencapai 180.613 jiwa. Sedangkan, jumlah kelahiran hidup di tahun yang sama adalah sebesar 2.836 jiwa. $^{7}$

Kelurahan Pegirian merupakan salah satu kelurahan di Kecamatan Semampir. Kelurahan Pegirian memiliki jumlah penduduk sebesar 31.874 jiwa. Jumlah kelahiran hidup di Kelurahan Pegirian pada tahun 2016 adalah sebanyak 473. Sedangkan, kasus kematian neonatal dan bayi yang terjadi adalah sejumlah 3 kasus. Capaian ASI eksklusif kelurahan Pegirian baru mencapai angka 56,76\%. ${ }^{8}$

Kebanyakan masyarakat Indonesia masih memberikan makanan dan minuman tambahan pada bayi usia 0-6 bulan, seperti pisang, madu, air gula, atau susu formula. Hal itu terjadi karena pengetahuan ibu hamil, keluarga, dan masyarakat mengenai ASI eksklusif pada bayi masih kurang. Masalah ini semakin parah dengan adanya promosi susu formula yang sangat gencar. Selain itu, belum ada tempat khusus menyusui serta kesempatan ibu menyusui pada institusi yang memiliki karyawan perempuan. ${ }^{5}$

Fenomena pemberian makanan tambahan selain ASI pada bayi juga terjadi di Kelurahan Pegirian. Padahal, keberhasilan pemberian ASI eksklusif pada bayi dalam 6 bulan pertama menjadi tolok ukur terhadap kelangsungan pemberian ASI pada bayi sampai usia 2 tahun. Oleh karena itu, sangat penting dilakukan penelitian mengenai faktor yang berhubungan dalam keberhasilan pemberian ASI eksklusif. Berbagai penelitian menunjukkan bahwa faktor yang memengaruhi keberhasilan pemberian ASI eksklusif yaitu faktor sosiodemografi ibu, meliputi usia, status pernikahan, pendidikan, dan tingkat penghasilan. Oleh karena itu, peneliti tertarik untuk melakukan penelitian mengenai faktor yang berhubungan dengan perilaku pemberian ASI eksklusif di Kelurahan Pegirian, Kecamatan Semampir, Kota Surabaya.

\section{METODE PENELITIAN}

Penelitian ini merupakan penelitian observasional karena hanya mendeskripsikan hasil tanpa memberikan tanpa memberikan perlakukan kepada responden. Penelitian 
dilakukan di Kelurahan Pegirian khususnya wilayah RT 06 RW 02 Kecamatan Semampir Kota Surabaya. Penelitian dilakukan pada bulan Januari 2018. Data yang digunakan merupakan data sekunder dari kegiatan Praktik Kerja Lapangan (PKL) Mahasiswa Fakultas Kesehatan Masyarakat Universitas Airlangga.

Subjek penelitian merupakan wanita usia subur (WUS) yang berusia 15-49 tahun, telah berstatus menikah dan pernah memiliki anak. Data yang digunakan meliputi data status bekerja, tingkat pendidikan, pengetahuan, sikap, dan perilaku ibu terkait pemberian ASI eksklusif. Data yang telah terkumpul kemudian diolah menggunakan aplikasi SPSS dan dianalisis secara deskriptif dan inferensial menggunakan chi-square.

\section{HASIL DAN PEMBAHASAN}

\section{Hasil}

\section{Karakteristik Responden}

Berikut merupakan data mengenai karakteristik responden.

Tabel 1. Distribusi Frekuensi Karakteristik WUS RT 06 RW 02 Kelurahan Pegirian Tahun 2018

\begin{tabular}{|c|c|c|}
\hline Karakteristik & Jumlah (n) & Persentase (\%) \\
\hline \multicolumn{3}{|l|}{ Status Bekerja } \\
\hline Bekerja & 6 & 22,2 \\
\hline Tidak Bekerja & 21 & 77,8 \\
\hline \multicolumn{3}{|l|}{ Pendidikan } \\
\hline$<\mathrm{SMP}$ & 20 & 74,1 \\
\hline$\geq \mathrm{SMP}$ & 7 & 25,9 \\
\hline $\begin{array}{ll}\text { Sumber: Lapor } \\
\\
\text { UNAI }\end{array}$ & $\begin{array}{c}\text { PKL } \quad \text { N } \\
\text { Tahun } 2018\end{array}$ & asiswa \\
\hline
\end{tabular}

Tabel 1 menunjukkan bahwa 77,8\% wanita usia subur di Kelurahan Pegirian tidak bekerja dalam arti kata produktif secara ekonomi, artinya mereka merupakan ibu rumah tangga yang tidak menghasilkan secara ekonomi. Berdasarkan pendidikan terakhir, $74,1 \%$ WUS memiliki tingkat pendidikan di bawah Sekolah Menengah Pertama (SMP), yaitu Sekolah Dasar (SD) atau lebih rendah.

\section{Karakteristik Responden Berdasarkan ASI}

\section{Eksklusif}

Karakteristik responden berdasarkan ASI eksklusif ditunjukkan tabel berikut.

Tabel 2. Karakteristik Responden Berdasarkan ASI Eksklusif.

\begin{tabular}{lrc}
\hline Karakteristik & Jumlah (n) & Persentase (\%) \\
\hline Pengetahuan & & \\
Baik & 12 & 44,4 \\
Kurang & 15 & 55,6 \\
\hline Sikap & & \\
Baik & 14 & 51,9 \\
Kurang & 13 & 48,1 \\
\hline Perilaku & & \\
Ya & 20 & 74,1 \\
Tidak & 7 & 25,9 \\
\hline
\end{tabular}

Sumber: Laporan PKL Mahasiswa FKM UNAIR Tahun 2018

Tabel 2 menunjukkan bahwa 55,6\% pengetahuan WUS tentang ASI eksklusif masih kurang. Meskipun demikian, 51,9\% sikap WUS terhadap ASI eksklusif sudah baik. Oleh karena itu, perilaku pemberian ASI eksklusif oleh WUS di Kelurahan Pegirian sudah baik dengan persentase sebesar $74,1 \%$. 
Analisis Faktor yang Berhubungan dengan

Perilaku Pemberian ASI Eksklusif

Berikut ini disajikan tabel yang berisi mengenai hasil analisis faktor-faktor yang berhubungan dengan perilaku dalam pemberian ASI eksklusif oleh para wanita usia subur (WUS) yang berusia 15-49 tahun di Kelurahan Pegirian, Kecamatan Semampir, Kota Surabaya.

Tabel 3. Faktor yang Berhubungan dengan Perilaku Pemberian ASI Eksklusif

\begin{tabular}{|c|c|c|c|c|c|c|c|}
\hline \multirow[t]{3}{*}{ Karakteristik } & \multicolumn{4}{|c|}{ ASI eksklusif } & \multirow[t]{3}{*}{$\sum$} & \multirow[t]{3}{*}{$\%$} & \multirow[t]{3}{*}{$P$ value } \\
\hline & \multicolumn{2}{|c|}{$\mathrm{Ya}$} & \multicolumn{2}{|c|}{ Tidak } & & & \\
\hline & $\mathrm{n}$ & $\%$ & $\mathrm{n}$ & $\%$ & & & \\
\hline \multicolumn{8}{|l|}{ Status Bekerja } \\
\hline Bekerja & 3 & 50,0 & 3 & 50,0 & 6 & 100,0 & \multirow{2}{*}{0,958} \\
\hline Tidak Bekerja & 13 & 61,9 & 8 & 38,1 & 21 & 100,0 & \\
\hline \multicolumn{8}{|l|}{ Pendidikan } \\
\hline$<\mathrm{SMP}$ & 11 & 55,0 & 9 & 45,0 & 20 & 100,0 & \multirow{2}{*}{0,753} \\
\hline$\geq$ SMP & 5 & 71,4 & 2 & 28,6 & 7 & 100,0 & \\
\hline \multicolumn{8}{|l|}{ Pengeluaran } \\
\hline$\leq 1$ juta & 8 & 61,5 & 5 & 38,5 & 13 & 100,0 & \multirow{2}{*}{1,000} \\
\hline$>1$ juta & 8 & 57,1 & 6 & 42,9 & 14 & 100,0 & \\
\hline \multicolumn{8}{|l|}{ Pengetahuan } \\
\hline Baik & 11 & 91,7 & 1 & 8,3 & 12 & 100,0 & \multirow{2}{*}{0,008} \\
\hline Kurang & 5 & 33,3 & 10 & 66,7 & 15 & 100,0 & \\
\hline \multicolumn{8}{|l|}{ Sikap } \\
\hline Baik & 10 & 83,3 & 2 & 16,7 & 12 & 100,0 & \multirow{2}{*}{0,047} \\
\hline Kurang & 6 & 40,0 & 9 & 60,0 & 15 & 100,0 & \\
\hline
\end{tabular}

Berdasarkan Tabel 3 di atas menunjukkan bahwa proporsi WUS yang bekerja dan tetap memberikan ASI eksklusif adalah sebesar 50\%. Angka ini sama dengan WUS bekerja tetapi tidak memberikan ASI eksklusif yaitu sebesar $50 \%$. WUS yang tidak bekerja dan memberikan ASI eksklusif adalah sebesar 61,9\%. Sehingga masih cukup banyak yang tidak memberikan ASI eksklusif. Berdasarkan uji chi square yang telah dilakukan diperoleh $\mathrm{p}$ value $(0,958)>$ alpha $(0,05)$ sehingga tidak ada hubungan antara status pekerjaan dengan perilaku pemberian ASI eksklusif.
Proporsi WUS dengan pendidikan lebih rendah dari SMP dan memberikan ASI eksklusif sebesar 55\%. Sedangkan WUS dengan pendidikan SMP ke atas yang memberikan ASI eksklusif adalah sebesar 71,4\%. Hasil uji chi square yang diperoleh yaitu $p$ value $(0,753)>$ alpha $(0,05)$ sehingga tidak ada hubungan antara tingkat pendidikan dengan perilaku pemberian ASI eksklusif.

Responden yang memiliki pengetahuan yang baik tentang ASI eksklusif sebesar 91,7\% memberikan ASI eksklusif bagi bayinya. Sedangkan $60 \%$ responden dengan pengetahuan 
yang kurang tentang ASI eksklusif tidak memberikan ASI eksklusif bagi bayinya. Hasil uji chi square menunjukkan bahwa $p$ value $(0,008)<$ alpha $(0,05)$, sehingga terdapat hubungan antara pengetahuan tentang ASI eksklusif dengan perilaku pemberian ASI eksklusif.

Sebesar 83,3\% responden yang memiliki sikap yang baik terhadap ASI eksklusif memberikan ASI eksklusif bagi bayinya. Sedangkan, $60 \%$ responden dengan sikap yang kurang terkait ASI eksklusif tidak memberikan ASI eksklusif bagi bayinya. Hasil uji Fisher Exact yang dilakukan menunjukkan bahwa $p$ value $(0,047)<$ alpha $(0,05)$ sehingga terdapat hubungan antara sikap responden terkait ASI eksklusif dengan perilaku pemberian ASI eksklusif.

\section{Pembahasan}

\section{Status Bekerja}

Berdasarkan hasil penelitian yang ditunjukkan pada Tabel 3, bahwa tidak ada hubungan antara status bekerja dengan perilaku pemberian ASI eksklusif. Hal ini terjadi karena berdasarkan penelitian ini, sebagian besar responden tidak bekerja, yaitu 21 dari 27 responden atau sekitar 77,78\%. Sedangkan, perilaku pemberian ASI eksklusif pada responden yang tidak bekerja maupun bekerja hampir terbagi secara merata ada yang memberikan ASI eksklusif dan ada yang tidak. Oleh karena itu, tidak terbentuk kecenderungan atau hubungan yang signifikan antara status bekerja dengan perilaku pemberian ASI eksklusif.

Sebenarnya, sudah seharusnya bagi seorang ibu untuk memberikan ASI eksklusif bagi bayinya, tanpa memperhatikan status bekerja atau tidak bekerja. Meskipun bekerja, ibu tetap dapat memberikan ASI bagi bayinya dengan cara selalu memerah susu dan menyimpannya di lemari pendingin agar dapat diberikan kepada bayinya saat ibu sedang bekerja atau tidak berada di rumah. Sedangkan, bagi ibu yang tidak bekerja, mereka memiliki waktu yang lebih banyak bersama bayinya sehingga seharusnya mampu untuk terus memberikan ASI bagi bayinya ketika dibutuhkan.

Beberapa penelitian lain menunjukkan hasil yang berbeda terkait hubungan antara status bekerja dengan perilaku pemberian ASI eksklusif. Heryanto pada tahun 2017 menyatakan adanya hubungan yang bermakna antara status bekerja dengan pemberian MP ASI dini. ${ }^{9}$ Kumalasari, dkk di tahun 2015 juga menyatakan adanya hubungan yang bermakna antara aktivitas ibu dengan pemberian MP ASI dini. ${ }^{10}$ Sari di tahun 2015 juga menyatakan adanya hubungan status bekerja dengan pemberian ASI eksklusif. ${ }^{11}$

Berdasarkan penelitian-penelitian di atas, disebutkan bahwa ibu yang bekerja cenderung tidak akan memberikan ASI eksklusif bagi bayinya, sedangkan ibu yang tidak bekerja cenderung akan memberikan ASI eksklusif bagi 
bayinya. Alasan yang diperoleh terkait ibu bekerja yang tidak memberikan ASI eksklusif adalah terkait waktu yang digunakan untuk bekerja sehingga tidak dapat memberikan ASI secara teratur dan akhirnya menghentikan pemberian ASI eksklusif. Selain itu, status pekerjaan dan status sosial ekonomi yang baik menjadikan ibu dapat dengan mudah memberikan susu formula atau MP ASI lainnya untuk menggantikan ASI eksklusif. ${ }^{9}$ Alasan lain mengapa ibu bekerja tidak memberikan ASI eksklusif yaitu adanya stres akibat faktor pekerjaan yang mengganggu produksi ASI sehingga memutuskan untuk memberikan susu formula atau MP ASI lainnya. ${ }^{10}$

Alasan-alasan di atas, sebenarnya dapat diatasi apabila ibu benar-benar ingin memberikan ASI eksklusif bagi bayinya. Caranya adalah dengan memerah susu dan menyimpannya di lemari pendingin sehingga susu dapat diberikan pada bayi disaat ibu sedang bekerja.

\section{Tingkat Pendidikan}

Berdasarkan Tabel 3, tingkat pendidikan ibu tidak memiliki hubungan yang signifikan terhadap perilaku pemberian ASI eksklusif. Hal ini terjadi karena tingkat pendidikan sebagian besar responden sama, yaitu lebih rendah dari SMP. Persentase responden yang memiliki tingkat pendidikan lebih rendah dari SMP adalah sebesar 74,07\%. Responden yang memiliki pendidikan di bawah SMP hampir terbagi rata dalam perilaku pemberian ASI eksklusif, yaitu $55 \%$ memberikan dan $45 \%$ tidak memberikan
ASI eksklusif. Oleh karena itu tidak terbentuk kecenderungan atau hubungan antara tingkat pendidikan dengan perilaku pemberian ASI eksklusif.

Pada dasarnya, setiap ibu harus memberikan ASI kepada bayinya tanpa memperhatikan tingkat pendidikan mereka. Baik ibu dengan pendidikan rendah maupun tinggi seharusnya memberikan ASI bagi bayinya karena ASI merupakan makanan pertama dan terbaik bagi bayi.

Akan tetapi, beberapa penelitian lain menunjukkan hasil yang berbeda. Penelitian oleh Sunesni, dkk tahun 2018 menyatakan adanya hubungan antara tingkat pendidikan dengan perilaku pemberian ASI eksklusif. ${ }^{12}$ Penelitian oleh Hartini tahun 2014 juga menyatakan adanya hubungan yang signifikan antara tingkat pendidikan dengan perilaku pemberian ASI eksklusif. ${ }^{13}$ Hal tersebut terjadi karena karena semakin tinggi tingkat pendidikan seseorang, maka semakin mudah untuk menerima informasi dan semakin banyak pengetahuan yang dimiliki.

Oleh karena itu, penelitian-penelitian yang menyatakan adanya hubungan antara tingkat pendidikan dengan perilaku pemberian ASI eksklusif menyatakan bahwa semakin tinggi tingkat pendidikan, maka semakin cenderung untuk memberikan ASI eksklusif. Hal tersebut dipengaruhi oleh semakin tinggi tingkat pendidikan ibu maka pengetahuan tentang ASI eksklusif juga akan meningkat. 
Akan tetapi, dengan semakin berkembangnya zaman, akses terhadap informasi menjadi lebih mudah dilakukan. Adanya televisi, internet, handphone, komputer dan berbagai alat komunikasi lainnya, akses informasi menjadi sangat terbuka dan tidak terbatas $^{14}$. Oleh karena itu, seharusnya para ibu dapat memanfaatkan kemudahan-kemudahan tersebut untuk meningkatkan informasi dan penegetahuannya terkait ASI eksklusif sehingga dapat memahami pentingnya pemberian ASI eksklusif bagi bayinya, tanpa memperhatikan tingkat pendidikannya.

\section{Pengetahuan}

Berdasarkan tabel 3, terdapat hubungan antara pengetahuan responden mengenai ASI eksklusif dengan perilaku pemberian ASI eksklusif. Hal ini sejalan dengan hasil dari beberapa penelitian lain. Rachmaniah tahun 2014 menyatakan adanya hubungan antara pengetahuan ibu tentang ASI terhadap tindakan pemberian ASI eksklusif. ${ }^{15}$ Penelitian lain oleh Safitri tahun 2017 juga menyatakan adanya hubungan antara pengetahuan mengenai ASI eksklusif dengan pemberian ASI eksklusif. ${ }^{16}$ Lestari tahun 2013 juga menyatakan adanya hubungan yang bermakna antara pengetahuan mengenai ASI eksklusif dengan perilaku pemberian ASI eksklusif. ${ }^{17}$ Penelitian-penelitian tersebut menyatakan bahwa pengetahuan yang dimiliki ibu akan membentuk kesadaran ibu akan pentingnya ASI eksklusif. Oleh karena itu, ibu yang memiliki pengetahuan yang baik mengenai ASI eksklusif cenderung mempunyai perilaku yang baik untuk memberikan ASI eksklusif untuk bayinya. ${ }^{17}$

Pengetahuan merupakan faktor yang dominan dalam membentuk perilaku seseorang. Meskipun pengetahuan tidak berdiri sendiri, pengetahuan merupakan faktor yang perlu dikembangkan untuk membentuk perilaku. Alasannya adalah perilaku yang terbentuk atas dasar pengetahuan akan bertahan lebih lama daripada perilaku tanpa dasar pengetahuan. ${ }^{16}$

Seringkali, tingkat pengetahuan dikaitkan dengan tingkat pendidikan. Hal tersebut terjadi karena pendidikan menjadi sumber pembuka wawasan seseorang sehingga dapat meningkatkan pengetahuannya. Akan tetapi, pada saat ini sumber informasi dapat diperoleh dari mana saja, tidak hanya dari bangku sekolah. Oleh karena itu, setiap orang harus terbuka akan informasi-informasi baru yang dibutuhkannya. Dalam hal ini, adalah informasi mengenai pentingnya ASI eksklusif bagi bayi yang harus diketahui oleh para ibu. Dengan demikian, mereka akan secara sadar mempraktikan ASI eksklusif demi memenuhi kepentingan bayinya.

\section{Sikap}

Tabel 3 menunjukkan adanya hubungan antara sikap ibu dengan perilaku pemberian ASI eksklusif. Hal ini sesuai dengan penelitian dari Lubis tahun 2017, bahwa terdapat hubungan yang bermakna antara sikap ibu dengan perilaku pemberian ASI eksklusif. ${ }^{18}$ Akan tetapi, berlawanan dengan hasil penelitian dari 
Yulianah, dkk tahun 2013, yang menyatakan bahwa tidak ada hubungan antara sikap ibu dengan perilaku pemberian ASI eksklusif. ${ }^{19}$

Pengetahuan berperan penting dalam menentukan seseorang dalam bersikap yaitu bersikap positif maupun negatif. Tindakan seseorang akan terbentuk dari pengetahuan atau kognitif yang dimiliki oleh orang tersebut. ${ }^{20}$ Berdasarkan penelitian yang dilakukan Lubis, sikap ibu yang positif terhadap ASI eksklusif terbentuk karena pengetahuan yang baik mengenai ASI eksklusif, sedangkan sikap yang negatif terhadap ASI eksklusif terbentuk karena pengetahuan yang kurang mengenai ASI eksklusif. ${ }^{18}$ Demikian pula di dalam penelitian ini, pengetahuan juga membentuk sikap responden yang pada akhirnya membentuk perilaku responden. Pengetahuan yang baik membentuk sikap yang baik dan akhirnya menjadikan responden melakukan pemberian ASI eksklusif bagi bayinya. Sebaliknya, pengetahuan yang kurang, membentuk sikap yang kurang dan menjadikan responden tidak memberikan ASI secara eksklusif untuk bayinya.

\section{SIMPULAN DAN SARAN}

\section{Simpulan}

Berdasarkan penelitian yang telah dilakukan diperoleh kesimpulan bahwa faktor yang berhubungan dengan perilaku pemberian ASI eksklusif di Kelurahan Pegirian Kecamatan
Semampir Kota Surabaya adalah pengetahuan dan sikap ibu terhadap ASI eksklusif.

\section{Saran}

Saran yang dapat diberikan bagi Puskesmas Pegirian sebagai fasilitas pelayanan kesehatan terdekat untuk memberikan penyuluhan terkait ASI eksklusif bagi ibu hamil dan menyusui di Kelurahan Pegirian untuk meningkatkan pengetahuan mereka. Materi penyuluhan tidak hanya berisi tentang pentingnya ASI saja, akan tetapi dapat ditambahkan solusi atau alternatif bagi ibu bekerja yang tidak dapat selalu menyusui bayinya ketika bekerja.

Kader setempat dapat melakukan pendampingan bagi ibu menyusui agar mereka melakukan pemberian ASI eksklusif untuk bayinya, terutama pada ibu muda yang baru memiliki anak pertama dan belum memiliki cukup pengalaman dalam merawat bayi.

\section{DAFTAR PUSTAKA}

1. Gupta, A., Padhich, J. P., Suri, S. How Global Rates of Exclusive Breastfeeding For The First 6 Months Be Enhanced. ICAN. Vol. 5(3): 133-140, 2013.

2. Moehji, S. Ilmu Gizi 2 Penanggulangan Gizi Buruk. Jakarta. PT. Bhatara Niaga Media. 2003.

3. Septiani, H., Budi, A. dan Karbito. Faktorfaktor yang Berhubungan dengan Pemberian ASI Eksklusif oleh Ibu Menyusui yang Bekerja sebagai Tenaga Kesehatan. Lampung. Jurnal Aisyah: Jurnal Ilmu Kesehatan. 2 (2), 159-174. 2017.

4. BPS. Survei Sosial Ekonomi Nasional (SUSENAS) Tahun 2010. Jakarta. 2010. 
5. Kementerian Kesehatan RI. Riset Kesehatan Dasar Tahun 2013. Jakarta. Badan Penelitian dan Pengembangan Kesehatan Kemenkes RI. 2013.

6. Dinas Kesehatan Provinsi Jawa Timur. Profil Kesehatan Provinsi Jawa Timur Tahun 2016. Jawa Timur. 2017.

7. BPS Kota Surabaya. Kecamatan Semampir dalam Angka Tahun 2016. Surabaya. 2018.

8. Dinas Kesehatan Kota Surabaya. Profil Kesehatan Tahun 2016. Surabaya. 2017.

9. Heryanto, E. Faktor-faktor yang Berhubungan dengan Pemberian Makanan Pendamping ASI Dini. Jurnal Aisyah: Jurnal Ilmu Kesehatan. 2 (2), 141-152. 2017.

10. Kumalasari, S.Y., Febriana S., dan Oswati H. Faktor-faktor yang Berhubungan dengan Pemberian Makanan PendampingASI Dini. Riau. JOM Vol. 2 No. 1. 2015.

11. Sari, J.L. Hubungan Status Ibu Bekerja dengan Pemberian ASI Eksklusif pada Ibu Menyusui di Puskesmas Umbulharjo I Yogyakarta. Yogyakarta. STIKES 'Aisyiyah Yogyakarta. 2015.

12. Sunesni, D. dan Putri, A. Hubungan Pendidikan dan Pengetahuan Ibu tentang ASI Perah dengan Praktik Pemberian ASI Perah. Padang. Jurnal Endurance 3(2) Juni 2018 (415-421). 2018.

13. Hartini, S. Hubungan Tingkat Pendidikan Ibu dengan Keberhasilan ASI Eksklusif pada Bayi Umur 6-12 Bulan di Puskesmas Kasihan II Yogyakarta. Yogyakarta. STIKES 'Aisyiyah Yogyakarta. 2014.

14. Ngafifi, M. Kemajuan Teknologi dan Pola Hidup Manusia dalam Perspektif Sosial Budaya. Wonosobo. 2014.

15. Rachmaniah, N. Hubungan Tingkat Pengetahuan Ibu tentang ASI dengan Tindakan ASI Eksklusif. Surakarta. Universitas Muhammadiyah Surakarta. 2014.

16. Safitri, H. Hubungan Pengetahuan Ibu tentang ASI Eksklusif dengan Pemberian ASI
Eksklusif (Studi Meta Analisis). Medan. Repositori Institusi USU. 2017.

17. Lestari, A.R. Hubungan Tingkat Pengetahuan tentang ASI Eksklusif dan Paritas Ibu Menyusui dengan Pemberian ASI Eksklusif di Puskesmas Sewon II Bantul Tahun 2013. Yogyakarta. STIKES 'Aisyiyah Yogyakarta. 2013.

18. Lubis, I. Hubungan Karakteristik, Pengetahuan, dan Sikap Ibu dengan Pemberian ASI Eksklusif di Wilayah Kerja Puskesmas Binjai Serbangan Kecamatan Air Joman Kabupaten Asahan Tahun 2017. Medan. Repositori Institusi USU. 2017.

19. Yulianah, N., Bahar, B. dan Salam, A. Hubungan Antara Pengetahuan, Sikap, dan Kepercayaan Ibudengan Pemberian ASI Eksklusif di Wilayah Kerja Puskesmas Bonto Cani Kabupaten Bone Tahun 2013. Sulawesi Selatan. Universitas Hasanudin. 2013.

20. Notoatmodjo, S. Pendidikan Dan Perilaku Kesehatan. Jakarta. Rineka Cipta. 2003. 